УДК 17.023.34:2-1: 141.144(477) (092)

https://orcid.org/0000-0001-7112-9723

\title{
ЩАСТЯ ЯК ПЕРСОНАЛІСТИЧНИЙ ФЕНОМЕН У ФІЛОСОФСЬКІЙ ДУМЩ С. Б. КРИМСЬКОГО
}

Р.А. Горбань, доктор філософських наук, професор кафедри історії мистецтва та гуманітарних дисциплін Косівського інституту прикладного та декоративного мистецтва Львівської національної академії мистецтв

У статті розглянуто інтерпретацію феномену щастя С.Б. Кримським, який пов'язує проблему його пошуків з розвитком принципів духовності XXI століття та розвитком особовості, щуо стає актуальним у новітню епоху інформаційних технологій, оскільки духовно розвинута відповідальна особа здатна не тільки дати адекватну відповідь на тотальне прискорення сучасного буття, а ц̆ зробити щасливою себе та інших, реалізувавши у такий спосіб сенс свого життя. Доведено, щуо у визначеному начіональним світоглядом і релігійно зумовленому філософському дискурсі украйнського публічного мислителя в діалогічний спосіб окреслюються духовний, иіннісно-смисловий, трансиендентний, етичний $i$ практичний аспекти щзастя. Воно постає як персоналістичний феномен, пов'язаний із прозопойчним сенсожиттєвим смислотворенням і творенням людиною у процесі ї̈ життєдіяльності своєї особи.

Ключові слова: духовність, щуастя, особа, третя правда, любов, сенс життя, вічність, природа.

Постановка проблеми. У 2018 році Україна зайняла сьоме місце в рейтингу «нещасливих країн». Цей антирейтинг щастя вираховувало для шістдесяти шести країн на підставі прогнозів економістів щодо інфляції та безробіття американське агентство «Bloomberg», яке є провідним у світі постачальником фінансової інформації [20]. Однак зазначений показник оцінки щастя насправді виявляється відносним, оскільки враховує лише економічний фактор і жодним чином не відображає систему культурних, історичних, соціальних і духовних координат, в якій перебуває Україна. Сучасний вітчизняний учений, фахівець із соціальної філософії В. В. Левкулич серед багатоманітності цінностей, що зберігають позитивне значення в усі часи й народи, виділяє передусім життя, здоров’я та щастя [10, c. 222]. Щастя - це світоглядна цінність, уявлення про яку формується у свідомості кожної людини не лише під впливом їі вузького соціальнокультурного оточення, а й у контексті більш широкого культурноісторичного середовища, яким $є$ нація, отже, на основі національної 
світоглядної думки, виявленої насамперед у фольклорі, філософії, літературі.

3 огляду на рейтинг «нещасливих країн» світу парадоксальним $є$ те, що найцінніша за номінальною вартістю банкнота української національної валюти містить зображення українського філософа, який стверджував: «Царство Боже всередині нас. Щастя в серці, серце в любові, любов же - в законі вічного» $[19$, с. 140$]$. Вшанований у такий спосіб українцями вітчизняний мислитель обгрунтував свою філософію щастя на засадах категорії вічності та витлумачив буття людської особи як шлях до Бога. Цей факт здається нелогічним збігом обставин, безглуздям, але, звичайно, тільки на перший погляд, позаяк він висвітлює як очевидне те, що не економіка виведе українців з усіх криз, а розвиток духовності.

Аналіз останніх досліджень i публікацій. Ключові вектори української філософської думки, які поставали й розвивалися до і після Григорія Сковороди, сходяться у фокусі його особи. Це стосується й філософського осмислення феномену щастя. Тому цілком логічно, що зусилля вітчизняних науковців в опрацюванні філософської рефлексії щастя були спрямовані переважно на дослідження доробку саме цього барокового мислителя. Так, на понятті щастя як одному 3 головних у філософії Сковороди зосереджували увагу вже починаючи від XIX століття і до сьогодні Ф.О. Зеленогорський (1894), Д.І. Багалій (1926), Д.І. Чижевський (1931), М.П. Редько (1961), I.I. Іваньо (1969), А.І. Пашук (1973), Н.М. Корнієнко (1992), М.Г. Фіглевський (1994), .Ю. Гузар (1995), Д.Б. Чопик (1996), Є.I. Лащик (1997), О.М. Данилевська (1998), І.Ю. Куташ (2000), Г.М. Сагач (2000), Н.П. Дічек (2002), І.О. Жифарська (2003), С.П. Пінчук (2003), С.О. Ярмусь (2003), Л.В. Ушкалов (2004), Т.В. Белімова (2007), А.О. Будугай (2007), Я.П. Гвоздецький (2007), Л.Я. Жук (2007), В.А. Куц (2007), В.П. Манженко (2007), Н.А. Михайловська (2007), Л.І. Тараненко (2007), І.3. Майданюк (2011), А.В. Грабська (2012), I.M. Савицька й І.В. Каменська (2016), С.В. Вівчар (2018) та інші. Ретроспекцію розвитку філософії щастя до Григорія Сковороди від XV до 
XVIII століть подано у працях В. Д. Литвинова (2003), а від другої половини XVI до першої третини XVII століть - у працях М.В. Дойчика $(2004,2006)$. Є також роботи, присвячені вченню про щастя, окремих українських мислителів цього ж періоду: стаття Є. М. Лимар про філософа XVII століття Лазаря Барановича (1997) та підрозділ у монографії В. Д. Литвинова про філософа XVI століття Станіслава Оріховського (2014). Очевидним є брак наукових розвідок, предметом яких виступає категорія щастя, у філософському національному дискурсі після Сковороди. Це питання лише побіжно виникає у контексті наукового з'ясування інших філософських чи філософсько-релігійних проблем, приміром у працях 3 релігієзнавства професора А.М. Колодного, що стосуються філософсько-релігійного світогляду Тараса Шевченка, Івана Франка, Андрея Шептицького, Івана Огієнка, Арсена Річинського, Лева Силенка, Івана Ортинського, Святомира Фостуна [4].

Формування цілей статті. Метою статті $є$ дослідження концепції сучасного українського філософа Сергія Кримського, який пов'язує категорію щастя 3 розвитком духовності. На думку цього мислителя, духовність у XXI столітті стає гарантом збереження повноти людської екзистенції, яка протистоїть тотальній універсалізації матеріального інтересу та домінуванню прагматичних цілей і цінностей над духовними - загрозі, створеній у процесі глобалізації ринкових відносин [6, с. 5].

Виклад основного матеріалу. Представник Київської філософської школи професор С. Б. Кримський репрезентує інтровертний, екзистенційнософійно-кордоцентричний вектор, сконцентрований у філософії Сковороди в єдину систему взаємообумовлених екзистенціалів і архетипів української ментальності та філософських концептів, зокрема це «любов», «свобода», «софійність», «самопізнання» і «самотворення», «гідність», «істина-правда», плюралістична етика, релігійна толерантність, «Слово-мова», «добро», відповідальність особи за власний вибір, «щастя», що були інтегровані Григорієм Сковородою в органічно-цілісну «філософію серця» і в його 
філософському вченні та у філософських системах його послідовників, передусім Памфіла Юркевича, Миколи Бердяєва, Олександра Кульчицького, Сергія Кримського, утворили персоналістичний дискурс. Цей вектор сформувався в результаті тяглості філософської національної традиції, генеза якої відбувається понад півтори тисячі років на теренах України на підставі світоглядної парадигми української етнокультури, іiї ключових концептів, а також засвоєння національною філософською думкою персоналістичних інтенцій християнської та європейської філософії. На персоналістичний аспект в інтерпретації щастя вже у попередників Григорія Сковороди, представників українського ренесансного гуманізму, вказує професор В. Д. Литвинов, адже більшість цих мислителів розуміли щастя як «можливість і здійснення вільного й усебічного розвитку особи, як реалізацію людиною своїх творчих потенцій, як задоволення іiі духовних і тілесних потреб» [11, с. 105].

У своїх розмислах останніх років життя Сергій Кримський неодноразово повертався до проблеми щастя. Час від часу питання щастя з'являється у живій розмові з журналістами на шпальтах інтернет-видань, а саме в контексті діалогу. Діалог цікавий філософу тим, що «він ставить завдання доказати не те, що твій опонент неправий, а довести, що ми обоє належимо до деякої третьої царини істини, яка i $\epsilon$ для нас верховною цінністю», адже людину треба зрозуміти - «прилучити до власного досвіду», тому ідея діалогу поряд з ідеєю святості особи розглядається Кримським як декрет XXI століття [5]. Одне з останніх інтерв'ю, записане за місяць до смерті філософа, так і називається - «За межею щастя і нещастя», що свідчить про телеологічність поняття «щастя» як у філософії, так і у приватному житті філософа Сергія Кримського.

Телеологічність для Кримського $є$ не тільки цілеспрямуванням, а й «способом входження в майбутнє» [7, с. 49]. Досліджуючи освітні тенденції самореалізації філософської думки в сучасному світі, М. О. Дроботенко зауважує, що здійснення своєї культурної та освітньо-виховної місії 
філософом сьогодні неможливе без реалізації ролі діалогічного публічного інтелектуала, адже його інтелектуальне завдання орієнтоване на світоглядну сферу суспільства та полягає у залученні до діалогу й обговорювання тем, що мають важливе культурне та громадське значення [2, с. 124]. Отже, телеологічний аспект щастя, який спрямовано в майбутнє, а не лише на презентацію своїх філософських ідей сучасникам, виявляється принциповим для професора Кримського як публічного інтелектуала, адже дефініції щастя, які з'являються в процесі діалогу, що відбувається в інформаційному просторі інтернету, є сучасною формою демократизації філософських знань у новому соціумі, особливістю якого, за спостереженням Кримського, є «здатність до формування інформаційно-рольових сіток функціонування, вузлами яких виступають міри компетентності суб'єктів дії» [6, с. 30].

Очевидно, що така форма опрацювання проблематики, пов'язаної 3 феноменом щастя, значно розширює перспективи його пізнання. По-перше, у цей спосіб створюється варіативність гносеологічної траєкторії думки, адже множинність варіантів думки, за словами Кримського, посилює творчий потенціал пошуку найбільш ефективного шляху до реалізації поставленої мети [7, с. 132]. По-друге, така методологія формулювання й презентації філософських ідей дозволяє усвідомити й апробувати згенероване власною думкою розуміння щастя в контексті «третьої правди», яку український філософ тлумачить як панорамне бачення життєвих обставин, що дає йому можливість вивести осягнення сенсу щастя за межі жорсткого детермінізму бінарної опозиції «щастя/нещастя» у площину, обумовлену логікою цілого третьої правди, вищої за обидва поняття, де щастя не оцінюється мірою загальної кількості нещасть.

Для Кримського питання «Що таке щастя?» обумовлене питанням «У чому сенс життя?», оскільки обидва належать до так званих «вічних питань», а їхній зміст розкривається через їх обопільний зв'язок у смислотворенні буття особою. Мислитель говорить: «А що стосується сенсу життя, то можна дати таку відповідь: зроби щасливою хоча б одну людину і таким чином 
впиши себе у світову біографію добра» [17]. На переконання філософа, особа повинна творити сенсожиттєве середовище, яке дозволяє піднятися над повсякденністю і вижити навіть там, де, здавалося б, це неможливо зробити [1]. Цей процес $\epsilon$ побудовою своєї особи й обов'язком людини перед Богом, адже наділення людини особовістю, на погляд Кримського, є найвищим даром Бога - спроможністю розпоряджатися своєю людською природою. Філософ розглядає особу як морально самокеровану систему, яку розвиває належним чином далеко не кожна людина. Тому буття особою означає бути господарем самому собі, бути незалежним від контексту швидкозмінної ситуації [18]. 3 цього випливає, що найбільш адекватною формою існування людини в сучасному швидкозмінному світі стає буття особою.

Зауважена взаємообумовленість щастя і сенсу життя виявляється «мірою компетентності» його, Сергія Кримського, особистої філософської діяльності. Вона визначає зміст відповідей на «життєво важливі» й «смисложиттєво відповідальні» питання, які має поставити собі кожний філософ, оскільки вони дають змогу з'ясувати, чи стала філософія для нього лише професією, засобом для існування, і має свій рівень некомпетентності, що перетворює успіх на самовикриття й розчарування у своїй діяльності й у своєму житті, тож виявляється джерелом нещастя. Чи навпаки - філософія стала екзистенцією, способом людського особового буття, відкритого для необмеженого простору вічності, відтак узгоджується 3 християнським богословським поняттям щасливості, яке означає «усе те, що визначає остаточне здійснення долі усієї людини, наділеної ласкою в надприродному порядку» $[14$, с. 633]. Позаяк за критерій цих питань мислитель обирає відповіді Христа фарисею Никодиму (Ів. 3), предметом же їхнього діалогу є умова входження народженої від плоті людини до Царства Небесного. Оскільки до Царства Небесного ввійде лише той, хто «повторно народився від Духу», Кримський формулює зазначені питання так: 1) чи остаточно це народження сподіяне ним (філософом Сергієм Кримським)? 2) Чи зробив у своєму житті філософ те, що здійснюється не природним шляхом, а вимагає 
всього життя? 3) Чи зробив він своє життя адекватним своєму обов'язку, своїй долі, тобто чи зробив філософ у своєму житті щасливою хоча б одну людину? [13]. Тут важливо враховувати, що філософія в баченні Кримського є «смислотворенням життя», а філософ - людиною, здатною «переводити думки й почуття у свою біографію» [17]. Усі ці питання турбують українського мислителя упродовж років і знаходять уточнення та відповіді в контексті різних його діалогів-інтерв’ю.

Щодо першого питання, то в одній 3 останніх бесід Кримський говорить про духовність як створення власного внутрішнього світу, своєї особи i пояснює духовність безпосереднім зв'язком особи із трансцендентною особовою сферою, позаяк особовий Бог розмовляє 3 людиною через іiі особу [5]. Щодо другого питання, то в одному з діалогів він розповідає притчу про людину, яка хотіла купити щастя і на питання про ціну цієї покупки отримала відповідь: «Тридцять хвилин щастя вимагає півжиття!». На запитання «Чому така ціна?» їй відповіли, що це не ціна, а собівартість [1]. Щодо третього, то мислитель про висловлювання «зробити щасливою хоч одну людину» говорить, що тут йдеться про земне прилучення до Неба [16]. У такий діалогічний спосіб окреслюються духовний, ціннісносмисловий, трансцендентний, етичний і практичний аспекти феномену щастя як феномену персоналістичного - смислотворчого надбання людини в процесі їі життєдіяльності, що має стати процесом реалізації іiі особовості як дарованої Богом спроможності розпоряджатися своєю людською природою та спроможності здобути вічне буття.

У публічній лекції «Принципи духовності XXI століття», прочитаній у Національному університеті «Києво-Могилянська академія» й опублікованій на сайті видання «День»у листопаді 2002 року на вимогу читачів, які не потрапили на неї, оскільки конференц-зала не змогла вмістити всіх охочих, професор Кримський говорить про полісистемність як один із сучасних принципів духовності, згідно 3 яким у діяльності особи жодна мета не повинна бути єдиною, щоб іï реалізувати, треба мати на увазі систему цілей 
[8]. Очевидно, що для реалізації цілей необхідно виявити обставини, які уможливлюють здійснення поставлених цілей.

На переконання мислителя, життя людини є практичною відповіддю на питання «У чому полягає щастя?», тому він стверджує, що філософія може розглядати тільки проблему умов щастя. Натомість у сучасних філософських дослідженнях проблеми щастя як етичної категорії українські науковці, зокрема . М. Рохман (2010), виокремлюють два найбільш поширені визначення: 1) щастя - це спокій і безтурботність; 2) щастя - задоволення від володіння благами, здобутими в результаті діяльного життя [15, с. 162]. Така чітко структурована типологізація не може бути зручною для зазначеної вище обраної Кримським методології виявлення специфічних ознак щастя як персоналістичного феномену, яка є адекватною новітній епосі інформаційних технологій.

Підкреслюючи, що цією проблемою займається філософська антропологія, вчений обирає інший шлях і віднаходить умови, які утворюють щастя, в художній літературі, а саме в оповіданні американського романтика Едгара По «Муза Арнгейм, або Декоративне садівництво», очевидно, маючи на меті актуалізувати творчий аспект щастя як персоналістичного феномену. Кримський не випадково звертається до досвіду Е. По, який у кількох теоретичних есе, найбільше у «Поетичному принципі» та «Філософії композиції», розбудовує філософію творчості, блискуче реалізовану в його художній практиці, та стає зачинателем наукових дослідів поетичного мистецтва й засновником нових літературних жанрів. Про головного героя оповідання «Муза Арнгейм» Еллісона автор говорить наступне: «...якби не його витончена філософія, що не раз успішно надолужувала брак життєвого досвіду, то внаслідок уже самого надміру щастя він опинився б у вирі всіх нещасть, які чатують на винятково обдарованих» [12, с. 282]. Думка Едгара По про практичний і дієвий характер філософії, яка творить біографію іiі творця, та ідея відповідальності особи за свій дар є співзвучними концепції смислотворення Сергія Кримського та розуміння ним філософа як людини, 
здатної переводити думки та почуття у свою біографію. Філософська концепція паркової архітектури як мистецтва, матеріалом якого стає сама природа, викладена Едгаром По в оповіданні «Муза Арнгейм», сьогодні втілена в ландшафтному дизайні. Цей факт цілком вкладається в концепцію Кримського про те, що рано чи пізно істина, розроблена філософами, стає реальністю життя [21].

Використовуючи досвід пошуків американського письменника першої половини XIX століття, український філософ виділяє чотири умови щастя в їх сучасній інтерпретації: 1) природа; 2) любов; 3) відсутність марнославства; 4) духовність.

Усі вони представлені варіативно в кількох діалогах-інтерв'ю Кримського, що з'явилися на сайтах українських газет за чотири роки до смерті філософа: «3 усіх прав людини найважливішим є право бути іншим» (День: day.kiev.ua, січень 2006) [17], «Про мистецтво жити» (День: day.kiev.ua, липень 2007) [18], «Завжди дивіться на профіль. Його неможливо підробити, він повністю видає суть людини» (Gazeta.ua, лютий 2010) [3], «За межею щастя і нещастя» (ZN.UA, червень - липень 2011) [5]. Інваріанти кожної умови дозволяють розширити смисл самого поняття щастя, роблять його відкритим до добудови, головне - створюють ситуацію живого багатоголосся, діалогу, обміну думками, що дозволяє філософу «прилучити до власного досвіду» широке коло українських читачів.

Отже, перша умова щастя - це природа. Вона займає у філософіï Кримського особливе місце як один із базових архетипів української культури, що має винятково позитивний смисл. В українській культурі, на відміну він інших слов’янських культур, природа підноситься над язичницькою поетизацією зовнішнього буття, виступаючи резонатором людської душі. Діалог між людиною і природою відбувається не лише на рівні збігу фізіологічних ритмів, він має найвищий рівень входження до спільного для них обох символічного світу мудрості чи духовного життя; таке бачення природи в українському народному світогляді розвинулося у 
філософію софійності та сковородинську концепцію «третього світу» $[9$, c. 200].

Тому, розглядаючи природу як першу умову щастя, Кримський говорить, $з$ одного боку, про діалог людини з природою як запоруку фізичного i психічного здоров'я, наполягаючи, по-перше, на фізичних вправах на свіжому повітрі, адже справжнього здоров'я можна досягнути лише у такий спосіб [3]; по-друге, на прогулянках як спілкуванні з природою. Він говорить: «Якщо у людини депресія, то після походу в ліс, до річки або в поле вона, як правило, розсіюється. Більш того, ритм людських кроків, як встановлено наукою, збігається $з$ деякими ритмами мозку» [17]. На думку філософа, лише спілкування з тим, що вище за тебе, «дозволяє розрядити психічне напруження» [18], «розмагнічує і дає вихід» [5].

3 другого боку, Кримський говорить про діалог людини з природою як спілкування осіб. Як бачимо, українська ментальність з іï специфічним архетипом природи дозволяє це. Філософ наводить приклад з «Лісової пісні» Лесі Українки, коли Мавка - «сила природи, закохується в людину!» [5]. Скажемо більше: Мавка, жертвуючи собою задля іншої особи, яка стала для неї «абсолютним центром», сама стає особою. Цей особовий рівень діалогу визначає сенсожиттєві пошуки, що у тлумаченні Кримського мають три варіанти рішення, два 3 яких якраз і пов'язані 3 особовими зв'язкамивідношеннями людини з природою. Про перший з них філософ говорить, що треба вписати своє життя, як це роблять сільські люди, в життя природи, підпорядкувати свою життєдіяльність природним ритмам, тоді саме буття відповідає на питання про сенс життя. Другий полягає в тому, щоб зробити природу подією свого життя, як це зробив апокрифічний старець біблійних часів Осія: наприкінці життя віддав державі податки, кредиторам - гроші, дітям - майно, дружині - серце, а собі залишив місце під смоківницею, щоб спостерігати захід і схід сонця, звідки побачив те, що перевищує предметну вартість майна, грошей, садиби; перед ним відкрилися символи часу, світла, вічності, світу, що йде за горизонти повсякденності. Це означає: дати буттю 
проявитися в той чи інший спосіб через людську особу $[17 ; 18]$.

У ракурсі, запропонованому Кримським, проблема екології природи постає вже не як проблема чистого довкілля, а як проблема екології душі і тіла, як онтологічна проблема екології буття - онтологічного середовища, врівноваженої екосистеми прозопоїчних взаємозв'язків людини і природи, в якій і людина, і природа виступають абсолютним особовим центром.

Друга умова щастя - це любов. Говорячи про всі форми любові, проявлені у світовій культурі, Кримський актуалізує це поняття у двох аспектах: 3 одного боку, як любов жінки [3], як кохання [5], з другого - як духовну подію в особовому бутті, що «перетворюється на обмін особистостями» [18] і стає способом побачити абсолютний центр в іншій людині [17].

Третя умова щастя - це відсутність честолюбства i «зневага до марнославних думок» [3]. Марнославна людина ставить собі все нові й нові цілі, не може задовольнитися досягнутим, тому кар'єра зазвичай робиться ціною відмови від щастя $[17 ; 18]$. Вона робить кар'єру, рухаючись висхідною ієрархією посад, доки не досягає рівня своєї некомпетентності, що закінчується розчаруванням $[5 ; 18]$.

Четверта умова щастя - це духовність. Вона безпосередньо пов'язана 3 безперервними пошуками людиною сенсу свого життя, що і робить іiі особою, тобто йдеться про внутрішній творчий процес формування особи в контексті людської життєдіяльності. Кримський стверджує: духовність характеризується створенням внутрішнього світу людини, що перетворює іiі на самодостатню особу, якій внутрішня свобода дозволяє бути незалежною від обставин і кон’юнктури - «самій задавати сенс подій, а не сліпо слідувати за ходом соціальних змін» [18]. Отже, у його філософсько-релігійному дискурсі буття особи духовність визначає іï свободу волі та внутрішню мотивацію іiі поведінки. Духовність полягає, як говорить мислитель, у тому, щоб «зробити своє життя якомога повнішим, предметом наповнення високими цінностями» [17]. Цінності зумовлюють мету, яка вимагає 
постійного прагнення до неї, причому «ступінь досяжного щастя прямо пропорційний духовності та піднесеності цієї мети» [3]. Найвищий рівень скерованості мети полягає у тому, щоб зробити щасливими якнайбільше людей. Процес реалізації такої мети виявляється в інтерпретації філософа творенням людиною своєї особи, і це, за його словами, «може бути найбільшим і найважливішим явищем сучасності» [18]. Він переконаний, що особа є «найвищим даром Бога» [18], тому іï творення постає як процес формування суб’єкта, відповідального перед собою за близькість до інших або навіть до однієї людини - якщо він здатен зробити їі щасливою.

Виходячи 3 цього в одному 3 останніх своїх інтерв’ю філософ стверджує, що ідея «святості особи й ідея діалогу» мають стати у XXI столітті головною настановою людства, законом, якого мають дотримуватися у своїй життєдіяльності всі члени цієї глобальної спільноти. У цьому контексті Кримський актуалізує розроблену ним на початку 2000-х рр. концепцію нації як історичної особи. Він говорить, що «особою є не тільки індивід, є насамперед нація. Як історична особа кожна нація є неповторною, тому етнос стає особою і перетворюється на націю тоді, коли стає суб’єктом історичного розвитку» [5].

У цьому ракурсі щастя і духовність виявляються взаємообумовленими персоналістичними феноменами i постають у філософському дискурсі Кримського: перший як сенсожиттєве смислотворення і творення людиною своєї особи у процесі іiі життєдіяльності, а другий як культуротворчий i націотворчий процеси, саме він і визначає бачення, розуміння й оцінку феномену щастя у національному менталітеті. У світлі такої інтерпретації щастя на банкнотах української валюти візуалізовано справжні цінності нації як історичної особи в процесі її життєдіяльності, духовного та культурного становлення: Володимир Великий (град Володимира), Ярослав Мудрий (собор Святої Софії Київської), Богдан Хмельницький (Іллінська церква у Суботові), Іван Мазепа (Києво-Печерська лавра), Іван Франко (Львівський оперний театр імені Соломії Крушельницької), Михайло Грушевський 
(будівля Верховної Ради), Тарас Шевченко (Червоний корпус Київського національного університету), Леся Українка (Луцький замок), Григорій Сковорода (Києво-Могилянська академія). Ця візуалізація робить національну валюту України найсучаснішим за формою і змістом символом новітньої постіндустріальної епохи, в якій, на переконання Сергія Кримського, особа має стати абсолютним центром.

Висновки. Своє бачення професор С. Б. Кримський викладає не як кабінетний філософ, а у живій розмові з журналістами на сайтах української преси як публічний інтелектуал. Подібна сучасна форма діалогу дозволяє не тільки створити множинність варіантів гносеологічної траєкторії думки, а й усвідомити та апробувати згенероване власною думкою розуміння щастя в контексті «третьої правди», яку філософ тлумачить як панорамне бачення життєвих обставин, що дає йому можливість вивести осягнення сенсу щастя за межі жорсткого детермінізму бінарної опозиції «щастя/нещастя» у площину, обумовлену логікою цілого третьої правди, вищої за обидва поняття, де щастя не оцінюється мірою нещасть. У діалогічний спосіб окреслюються духовний, ціннісно-смисловий, трансцендентний, етичний i практичний аспекти феномену щастя як феномену персоналістичного смислотворчого надбання людини в процесі ії життєдіяльності, що має стати процесом реалізації іiі особовості як дарованої Богом спроможності розпоряджатися своєю людською природою та спроможності здобути вічне буття - святості особи. У національно визначеному і релігійно зумовленому філософському дискурсі українського мислителя щастя постає як персоналістичний феномен, пов'язаний із прозопоїчним сенсожиттєвим смислотворенням і творенням людиною у процесі ії життєдіяльності своєї особи. Філософ переконує, що духовно розвинута відповідальна особа здатна не тільки дати адекватну відповідь на тотальне прискорення сучасного буття, а й зробити щасливою себе та інших, реалізувавши у такий спосіб сенс свого життя.

Повертаючись до початку статті, маємо зауважити: насправді це не один рейтинг антищастя, в якому Україна займає невтішні позиції. Однак усі 
вони, як доводить Кримський, геть не сучасні, позаяк країну, нація якої має понадтисячолітній досвід власної присутності у світі як історична особа та тривалу історію розвитку духовної культури, не можна вимірювати в координатах опозиції «щастя/нещастя» в контексті прагматично зумовлених індексів щастя, тому що нація як суб'єкт історичного розвитку потребує панорамного бачення життєвих обставин, яке перевищує усталені уявлення про успіхи й поразки, - i це унаочнює персоналістична обумовленість банкнот національної валюти України.

Список використаних джерел

1. Височіючи над повсякденністю. Професор Сергій Кримський: Розвиток України в останні роки позначений згасанням енергетики Майдану (Записав Ігор Сюндюков) / Сергій Борисович Кримський // День: day.kiev.ua. - 2008. - 14 серпня. - URL: https://day.kyiv.ua/uk/article/panorama-dnya/visochiyuchi-nadpovsyakdennistyu (дата звернення 17.04.2019).

2. Дроботенко М. О. Філософ як громадський (публічний) інтелектуал / Мар'яна Олександрівна Дроботенко // Вісник Харківського національного педагогічного університету імені Г. С. Сковороди. Філософія. - 2018. - Вип. 51. - С. 124-136.

3. «Завжди дивіться на профіль. Його неможливо підробити, він повністю видає суть людини» (Записав Олексій Кузьменко) / Сергій Борисович Кримський // Gazeta.ua. - 2010. - 18 лютого. - URL: https://gazeta.ua/articles/opinions-journal/quotzavzhdi-divitsya-na-profil-jogo-nemozhlivo-pidrobiti-vin-povnistyuvidaye-sut-lyudiniquot/327948 (дата звернення 17.04.2019).

4. Колодний А. М. Релігійне життя України в особах його діячів і дослідників. Монографія / Анатолій Миколайович Колодний. - К.: Інтерсервіс, 2017. - 740 с.

5. Кримський С. Б. За межею щастя і нещастя (Записав Віктор Ціон) / Сергій Борисович Кримський // ZN.UA. - 2011. - Вип. № 23. - 24 червня - 1 липня. - URL: https://dt.ua/SOCIETY/za mezheyu schastya i neschastya.html (дата звернення 15.04.2019).

6. Кримський С. Б. Заклики духовності ХХХІ століття / Сергій Борисович Кримський. - К.: Видавничий дім «КМ Академія», 2003. - 32 с.

7. Кримський С. Б. Запити філософських смислів / Сергій Борисович Кримський. -К.: ПАРАПАН, 2003. 240 c.

8. Кримський С. Б. Принципи духовності XXI століття (Записав Ігор Сюндюков) / Сергій Борисович Кримський // День: day.kiev.ua. - 2002. - 15 листопада. - URL: https://day.kyiv.ua/uk/article/cuspilstvo/sergiykrimskiy-principi-duhovnosti-hhi-stolittya (дата звернення 17.04.2019).

9. Кримський С. Б. Українська культура та ії базові архетипи / Сергій Борисович Кримський // Collegium. 2004. - № 16. - С. 185-206.

10. Левкулич В. В. Справедливість як соціальний феномен: монографія / Левкулич Василь Васильович. Ужгород: Гельветика, 2018. - 480 с.

11. Литвинов В. Д. Ренесансний гуманізм в Україні / Володимир Дмитрович Литвинов. - К.: Основи, 2000. $472 \mathrm{c}$.

12. По Е. А. Провалля і маятник; [пер. з англ. К. О. Шахової] / Едгар Алан По. - Харків: Фоліо, 2006. $478 \mathrm{c}$.

13. «Побачити раніше невидиме». До ювілею професора Сергія Кримського (Записав Ігор Сюндюков) / Сергій Борисович Кримський // День: day.kiev.ua. - 2010. - 2 червня. - URL: https://day.kyiv.ua/uk/article/panorama-dnya/pobachiti-ranishe-nevidime (дата звернення 17.04.2019).

14. Рагнер К. Короткий теологічний словник; [пер. 3 нім. О. Авраменка] / Карль Рагнер, Герберт Форгрімлєр / за заг. ред. Владики Софрона Мудрого. - Л.: [б. в.], 1996. - 664 с.

15. Рохман Б. М. Щастя як етична категорія / Богдан Михайлович Рохман // Науковий вісник Чернівецького університету: Збірник наукових праць. Філософія. Вип. 534-535. - Чернівці: Чернівецький національний ун-т, 2010. - С. 162-166.

16. Світло доброти. Професор Сергій Кримський про святкову «тишу свідомості» (Записав Ігор Сюндюков) / Сергій Борисович Кримський // День: day.kiev.ua. - 2009. - 25 грудня. - URL: https:/day.kyiv.ua/uk/article/cuspilstvo/cvitlo-dobroti дата звернення 17.04.2019).

17. Сергій Кримський: «3 усіх прав людини найважливішим $є$ право бути іншим» (Записав Ігор Сюндюков) / Сергій Борисович Кримський // День: day.kiev.ua. - 2006. - 20 січня. - URL: https://day.kyiv.ua/uk/article/panorama-dnya/sergiy-krimskiy-z-usih-prav-lyudini-nayvazhlivishim-ie-pravo-buti- 
inshim (дата звернення 17.04.2019).

18. Сергій Кримський про мистецтво жити (Записав Ігор Сюндюков) / Сергій Борисович Кримський // День: day.kiev.ua. - 2007. - 13 липня. - URL: https://day.kyiv.ua/uk/article/nota-bene/sergiy-krimskiy-promistectvo-zhiti (дата звернення 17.04.2019).

19. Сковорода Г. С. Вступні двері до християнської добронравності; [пер. В. Шевчука] / Григорій Савич Сковорода // Сковорода Г. С. Твори: У 2 т. Т. 1. - К.: Обереги, 1994. - С. 140-149.

20. Украина попала в топ-10 несчастных стран // Капитал. 15.02.2018. - URL: https://www.capital.ua/ru/news/108139-ukraina-popala-v-top-10-neschastnykh-stran (дата звернення 15.04.2019).

21. Чекан О. Ранок мудріший за вечір / Олена Чекан // Тиждень.ua. - 2010. - 9 липня. - URL: https://tyzhden.ua/Publication/3633 (дата звернення 17.04.2019).

\section{References}

1. Vysochiiuchy nad povsiakdennistiu. Pofesor Serhii Krymskyi: Rozvytok Ukrainy v ostanni roky poznachenyi zhasanniam enerhetyky Maidanu (Zapysav Ihor Siundiukov) / Serhii Borysovych Krymskyi // Den: day.kiev.ua. 2008. - 14 serpnia. - URL: https://day.kyiv.ua/uk/article/panorama-dnya/visochiyuchi-nad-povsyakdennistyu (data zvernennia 17.04.2019).

2. Drobotenko M. O. Filosof yak hromadskyi (publishnyi) intelektual/ Mariana Oleksandrivna Drobotenko // Visnyk Kharkivskoho natsionalnoho pedahohichnoho universytetu imeni H. S. Skovorody. Filosofiia. - 2018. Vyp. 51. - S. 124-136.

3. «Zavzhdy dyvitsia na profil. Yoho nemozhlyvo pidrobyty, vin povnistiu vydaie sut liudyny» (Zapysav Oleksii Kuzmenko) / Serhii Borysovych Krymskyi// Gazeta.ua. - 2010. - 18 liutoho. - URL: https://gazeta.ua/articles/opinions-journal/_quotzavzhdi-divitsya-na-profil-jogo-nemozhlivo-pidrobiti-vin-povnistyuvidaye-sut-lyudiniquot/327948 (data zvernennia 17.04.2019).

4. Kolodnyi A. M. Relihiine zhyttia Ukrainy v osobakh yoho diiachiv i doslidnykiv. Monohrafiia / Anatolii Mykolaiovych Kolodnyi. - K.: Interservis, 2017. - 740 s.

5. Krymskyi S. B. Za mezheiu shchastia i neshchastia (Zapysav Viktor Tsion) / Serhii Borysovych Krymskyi // ZN.UA. - 2011. - Vyp. № 23. - 24 chervnia -1 lypnia. - URL: https://dt.ua/SOCIETY/za_mezheyu_schastya_i_neschastya.html (data zvernennia 15.04.2019).

6. Krymskyi S. B. Zaklyky dukhovnosti 21 stolittia/ Serhii Borysovych Krymskyi. - K.: Vydavnychyi dim «KM Akademiia», 2003. - $32 \mathrm{~s}$.

7. Krymskyi S. B. Zapyty filosofskykh smysliv / Serhii Borysovych Krymskyi. - K.: PARAPAN, 2003. - 240 s.

8. Krymskyi S. B. Pryntsypy dukhovnosti 21 stolittia (Zapysav Ihor Siundiukov) / Serhii Borysovych Krymskyi // Den: day.kiev.ua. - 2002. - 15 lystopada. - URL: https://day.kyiv.ua/uk/article/cuspilstvo/sergiy-krimskiy-principiduhovnosti-hhi-stolittya (data zvernennia 17.04.2019).

9. Krymskyi S. B. Ukrainska kultura ta ii bazovi arkhetypy / Serhii Borysovych Krymskyi // Collegium. - 2004. № 16. - S. 185-206.

10. Levkulych V. V. Spravedlyvist yak sotsialnyi fenomen: monohrafiia / Levkulych Vasyl Vasylovych. Uzhhorod: Helvetyka, 2018. -480 s.

11. Lytvynov V. D. Renesansnyi humanism v Ukraini / Volodymyr Dmytrovych Lytvynov. - K.: Osnovy, 2000. $472 \mathrm{~s}$.

12. Poe E. A. Provallia i maiatnyk; [per. z anhl. K. O. Shakhovoi] / Edgar Alan Poe. - Kharkiv: Folio, 2006. - 478 s.

13. «Pobachyty ranishe nevidome». Do yuvileiu profesora Serhiia Krymskoho (Zapysav Ihor Siundiukov) / Serhii Borysovych Krymskyi // Den: day.kiev.ua. - 2010. - 2 chervnia. - URL: https://day.kyiv.ua/uk/article/panoramadnya/pobachiti-ranishe-nevidime (data zvernennia 17.04.2019).

14. Rahner K. Korotkyi teolohichnyi slovnyk; [per. z nim. O. Avramenka] / Karl Rahner, Herbert Vorgrimler / za zah. red. Vladyky Sofrona Mudroho. - L.: [b. v.], 1996. - 664 s.

15. Rokhman B. M. Shchastia yak etychna katehoriia / Bohdan Mykhailovych Rokhman // Naukovyi visnyk Chernivetskoho universytetu: Zbirnyk naukovykh prats. Filosofiia. Vyp. 534-535. - Chernivtsi: Chernivetskyi natsionalnyi un-t, 2010. - S. 162-166.

16. Svitlo dobroty. Profesor Serhii Krymskyi pro sviatkovu «tyshu svidomosti» (Zapysav Ihor Siundiukov) / Serhii Borysovych Krymskyi // Den: day.kiev.ua. - 2009. - 25 hrudnia. - URL: https://day.kyiv.ua/uk/article/cuspilstvo/cvitlo-dobroti (data zvernennia 17.04.2019).

17. Serhii Krymskyi: «Z usikh prav liudyny naivazhlyvishym ye pravo buty inshym» (Zapysav Ihor Siundiukov) / Serhii Borysovych Krymskyi // Den: day.kiev.ua. - 2006. - 20 sichnia. - URL: https://day.kyiv.ua/uk/article/panorama-dnya/sergiy-krimskiy-z-usih-prav-lyudini-nayvazhlivishim-ie-pravo-butiinshim (data zvernennia 17.04.2019).

18. Serhii Krymskyi pro mystetstvo zhyty (Zapysav Ihor Siundiukov) / Serhii Borysovych Krymskyi // Den: day.kiev.ua. - 2007. - 13 lypnia. - URL: https://day.kyiv.ua/uk/article/nota-bene/sergiy-krimskiy-pro-mistectvozhiti (data zvernennia 17.04.2019).

19. Skovoroda H. S. Vstupni dveri do khrystyianskoi dobronravnosti; [per. V. Shevchuka] / Hryhorii Savych Skovoroda // Skovoroda H. S. Tvory: U 2 t. T. 1. - K.: Oberehy, 1994. - S. 140-149. 
20. Ukraina popala $\mathrm{v}$ top-10 neschastnyh stran // Kapital. 15.02.2018. - URL: https://www.capital.ua/ru/news/108139-ukraina-popala-v-top-10-neschastnykh-stran (data zvernennia15.04.2019). 21. Chekan O. Ranok mudrishyi za vechir / Olena Chekan // Tyzhden.ua. - 2010. - 9 lypnia. - URL: https://tyzhden.ua/Publication/3633 (data zvernennia 17.04.2019).

\title{
СЧАСТЬЕ КАК ПЕРСОНАЛИСТИЧЕСКИЙ ФЕНОМЕН В ФИЛОСОФСКОЙ МЫСЛИ С.Б. КРЫМСКОГО
}

\author{
Р.А. Горбань
}

В статье рассмотрена интерпретация феномена счастья С. Б. Крымским, который связывает проблему его поисков с развитием принципов духовности XXI века и развитием личности, что становится актуальным в новую эпоху информационных технологий, поскольку духовно развитая ответственная личность способна не только дать адекватный ответ на тотальное ускорение современного бытия, но и сделать счастливой себя и других, реализовав таким образом смысл своей жизни. Доказано, что в национально и религиозно обусловленном философском дискурсе украинского публичного мыслителя диалогическим способом определяются духовный, ценностно-смысловой, трансцендентный, этический и практический аспекты счастья. В философии Крымского счастье представлено как персоналистический феномен, связанный с прозопоичным продуцированием жизненных смыслов и созданием человеком своей личности в процессе жизнедеятельности.

Ключевые слова: духовность, счастье, личность, третья правда, любовь, смысл жизни, вечность, природа.

\section{HAPPINESS AS A PERSONALISTIC PHENOMENON IN THE PHILOSOPHICAL THOUGHT OF S.B. KRYMSKYI}

\section{R. Gorban}

This article deals with the way Serhii Krymskyi interprets the phenomenon of happiness in his philosophy, which combines the problem of the search for happiness with the development of spirituality in the 21st century. It has been found out that he teaches his vision of happiness not as an «armchair» philosopher, but in a lively conversation between journalists and a public intellectual on the pages of online publications. Such a modern form of dialogue allows one to create not only a multiplicity of options for the epistemological vector of thought, but also to realize and test the understanding of happiness generated by our own opinion in the context of the third truth, which the philosopher explains as an extensive vision of life circumstances, that enables him to take the meaning of happiness beyond the rigid determinism of the binary opposition happiness / unhappiness into the plane, stipulated by the logic of the whole third truth, exceeding both concepts, where happiness is not estimated by the degree of total unhappiness. The spiritual, value-semantic, transcendental, ethical and practical aspects of the phenomenon of happiness are described in a dialogue manner; as the phenomenon of happiness is a personalistic phenomenon that reflects human wealth in the process of his life activity, which should become the process of realization of his individuality as God-given ability to control his human nature and the ability to obtain eternity. Using the research experience of Edgar Poe, the American writer of the first half of the 19th century, the Ukrainian philosopher identifies four conditions for happiness in their modern interpretation: 1) nature; 2) love; 3) lack of vanity; 4) spirituality. Delineating the personalistic nature of each of these conditions, he proves the personalistic interdependence of happiness and the meaning of life, concentrated in the idea, and that the creation of a personality is the creation of a subject responsible for the relation with others, or even with one person - if he is able to make her happy. Thus, it is demonstrated that, according to the philosophy of Krymskyi, happiness is a personalistic phenomenon related to the meaningfulness of life and the person's self-moulding in the process of his life-sustaining activity.

Key words: spirituality, happiness, third truth, love, sense of life, eternity, God, nature. 